\title{
Hematopoietic transcription factor mutations and inherited platelet dysfunction
}

\author{
Natthapol Songdej and A. Koneti Rao
}

\author{
Address: Hematology-Oncology Section, Department of Medicine and the Sol Sherry, Thrombosis Research Center, Temple University School of \\ Medicine, Philadelphia, PA, USA \\ * Corresponding author: A. Koneti Rao, M.D., (koneti@temple.edu) \\ Fl000Prime Reports 2015, 7:66 (doi:10.12703/P7-66) \\ All FI000Prime Reports articles are distributed under the terms of the Creative Commons Attribution-Non Commercial License \\ (http://creativecommons.org/licenses/by-nc/3.0/legalcode), which permits non-commercial use, distribution, and reproduction in any medium, \\ provided the original work is properly cited. \\ The electronic version of this article is the complete one and can be found at: http://fl000.com/prime/reports/m/7/66
}

\begin{abstract}
The molecular and genetic mechanisms in most patients with inherited platelet dysfunction are unknown. There is increasing evidence that mutations in hematopoietic transcription factors are major players in the pathogenesis of defective megakaryopoiesis and platelet dysfunction in patients with inherited platelet disorders. These hematopoietic transcription factors include RUNXI, FLII, GATA-I, and GFIIB. Mutations involving these transcription factors affect diverse aspects of plateletproduction and function at the genetic and molecular levels, culminating in clinical manifestations of thrombocytopenia and platelet dysfunction. This review focuses on these hematopoietic transcription factors in the pathobiology of inherited platelet dysfunction.
\end{abstract}

\section{Introduction}

In most patients with inherited platelet dysfunction, the underlying molecular and genetic mechanisms remain unknown. Previous paradigms have focused on abnormalities in the 'end' responses of platelet aggregation and secretion studies and the investigation of postulated abnormal pathways and proteins. These approaches have been driven by existing knowledge of platelet mechanisms and come with limitations. At the genetic level, the focus has largely been on delineating mutations in the coding sequence of genes encoding the candidate proteins. Evidence is now available that in some patients with inherited platelet dysfunction the primary abnormality is a mutation in a hematopoietic transcription factor (TF), which can lead to altered downstream expression of numerous genes that affect diverse cellular pathways and can result in abnormalities in both platelet number and function $[1,2]$.

TFs regulate lineage-specific gene expression through binding of cis-regulatory sequences. Major hematopoietic TFs include the Runt-related transcription factor 1 (RUNX1), friend leukemia integration 1 (FLI1),
GATA-binding factor 1 (GATA-1), and growth factor independent 1B (GFI1B); these TFs act in a combinatorial manner to regulate hematopoietic lineage differentiation, megakaryopoiesis, and platelet production [3]. TF mutations may be more common in patients with inherited platelet dysfunction than previously considered. For example, Stockley and colleagues [2] recently reported results of next-generation sequencing studies in 13 unrelated patients suspected of having an inherited platelet defect from the UK Genotyping and Phenotyping of Platelets (UK-GAPP) study. Heterozygous RUNX1 or FLI1 mutations were uncovered in 6 of the 13 patients with excessive bleeding and impaired dense granule secretion and aggregation on activation; 5 of these patients also had thrombocytopenia. These findings highlight the importance of TF mutations in the pathogenesis of inherited platelet function defects. This review focuses on the TF mutations implicated in these disorders.

\section{RUNXI}

RUNX1-also known as core-binding factor subunit alpha-2 (CBFA2) and acute myeloid leukemia 1 
(AML1) - is a critical hematopoietic TF required for definitive hematopoiesis encoded by the RUNX1 gene located on chromosome 21 (21q22.12) [4]. In a murine model, generation of homozygous RUNX1 mutants was lethal in utero because of hemorrhage [5]. In humans, heterozygous RUNX1 mutation is associated with an autosomal dominant disorder, the familial platelet disorder with predisposition to acute myeloid leukemia (FPD/AML) (Mendelian Inheritance in Man [MIM] 601399), characterized by impaired megakaryopoiesis, quantitative and qualitative defects in platelet function, and over $40 \%$ risk of development of myelodysplastic syndrome (MDS) or AML at a median age of 33 years [6-9]. Several distinct RUNX1 mutations, ranging from point mutations to deletional mutations, have been identified in patients with FPD/AML, and most are in the conserved Runt domain near the $\mathrm{N}$-terminus, resulting in impaired binding of RUNX1 to cis-regulatory DNA sequences. In addition to the Runt domain, a mutation in the C-terminal transactivating domain (Y260X) has been identified [10]. Most RUNX1 mutations result in haplodeficiency, whereas some mutations may produce dominant-negative activity that has been proposed to increase leukemia risk $[7,10,11]$. Interestingly, several syndromic cases of deletion of chromosome 21q22 including RUNX1 have also been described, and affected individuals may have congenital thrombocytopenia and platelet dysfunction but develop MDS or AML at a much lower age (three cases ranging from 5 to 8 years) than observed in FPD/AML [7].

Numerous platelet abnormalities have been reported in patients with RUNX1 mutation, including dense or $\alpha$-granule storage pool deficiency (SPD) or both, impaired platelet responses of aggregation and secretion, reduced protein phosphorylation of myosin light chain and pleckstrin, and decreased activation of $\alpha \operatorname{IIb} \beta 3$ $[1,9,10,12]$. Platelet production of 12-hydroxyeicosatetraenoic acid and one specific protein kinase $\mathrm{C}$ isoform (PKC- $\theta$ ) have also been shown to be decreased $[12,13]$.

Platelet granule deficiency leading to impaired platelet function is an important abnormality associated with RUNX1 mutations. In 1969, Weiss and colleagues [14] described one of the first families with inherited platelet dysfunction due to reduced platelet ADP and ATP, indicating a dense granule SPD. This affected family and some others described with SPD of dense or $\alpha$-granules were later shown to carry RUNX1 mutations $[10,15]$. Other studies have also shown decreased $\alpha$-granule contents in association with RUNX1 mutations $[10,16]$. In one patient, platelet albumin and IgG, two constituents of the $\alpha$-granule, were decreased [12], which suggests a possible defect in uptake and storage of these proteins into $\alpha$-granules because neither protein is synthesized by megakaryocytes (MKs).

RUNX1 influences multiple genes involved in MK differentiation [3]. Platelet transcript profiling of a patient with RUNX1 haplodeficiency has shown numerous genes relevant to multiple pathways to be downregulated [17]. Several of these genes with prominent roles in platelet structure and function have been shown to be direct transcriptional targets of RUNX1. These genes include ALOX12 (12-lipoxygenase) [13], PF4 (platelet factor 4) [16], platelet MYL9 (myosin light chain) [18], and PRKCQ (protein kinase C-theta) [19]. Low expression of $c-M P L$ (thrombopoietin receptor) in RUNX1 mutation has been documented, providing an additional mechanism for thrombocytopenia in patients with FPD/AML [20]. More recently, NF-E2, which encodes a TF implicated in platelet granule development and $\alpha$ IIb $\beta 3$ signaling, has also been shown to be a transcriptional target of RUNX1 [9]. Thus, the defect in platelet number and function associated with RUNX1 haplodeficiency may result from abnormalities in multiple mechanisms. Recently, Connelly and colleagues [8] showed that targeted in vitro correction of RUNX1 mutation could recover the MK defects. The investigators differentiated induced pluripotent stem cells (iPSCs) from skin fibroblasts of two FPD/AML patients with Y260X mutation and showed reduced MK production and abnormalities in MK structure, such as abundance of vacuoles and deficiency of dense and $\alpha$-granules. Gene targeting corrected the RUNX1 mutation in two of seven cloned iPSCs. As compared with the patients with FPD/ $\mathrm{AML}$, the two corrected clones resulted in approximately $40 \%$ to $60 \%$ more $\mathrm{CD} 41^{+} \mathrm{CD} 42^{+}$MKs with rescue of phenotypic features of abnormal MK differentiation. Gene expression profiling also showed significant upregulation of $\mathrm{MK}$ genes in the corrected clones as compared with one of the patients with FPD/AML, and RUNX1 accounted for the differences. These studies constitute strong evidence that RUNX1 mutation is the cause of defective megakaryopoiesis in patients with FPD/AML. The studies also raise the intriguing potential for gene-targeting therapy for these patients in the future.

It should be noted that, from a clinical standpoint, defects in platelet number and function in patients with FPD/AML can be heterogenous. Patients commonly have mild to moderate thrombocytopenia with normal-sized platelets and, despite the platelet dysfunction, a mild to moderate bleeding tendency $[7,21]$. Some individuals may lack bleeding symptoms and thrombocytopenia $[7,21]$. These features have important implications for treatment, as previously described pedigrees have documented recurrence of leukemia following hematopoietic 
stem cell transplantation from an undiagnosed sibling donor with FPD/AML [21].

\section{FLII}

FLI1 is part of the E-twenty-six (ETS) family of TFs that plays a major role in megakaryopoiesis through its influence on the expression of multiple genes, including ITGA2B (glycoprotein IIb) [22], GP1BA (glycoprotein 1b alpha chain) [22,23], GP9 (glycoprotein 9) [22], and c-MPL (thrombopoietin receptor) [24]. Distal deletion of either the maternally or paternally derived chromosome 11 that includes the FLI1 locus (11q23.3-24) is associated with a rare autosomal dominant disorder, the Jacobsen syndrome (MIM 147791), and its accompanying platelet disorder, the Paris-Trousseau syndrome (MIM 188025) [25-28]. The clinical features of Jacobsen syndrome include mental retardation, abnormal craniofacial appearance, and abnormalities in multiple organ systems [29,30]. The Paris-Trousseau syndrome is characterized by congenital macrothrombocytopenia with giant $\alpha$-granules of 1 to $2 \mu \mathrm{m}$ in diameter in a subpopulation of circulating platelets (1\% to 5\%) and bone marrow dysmegakaryopoiesis [30]. On the platelet function aspect, thrombin-induced platelet release of $\alpha$-granule contents has been shown to be impaired. Platelet survival is normal, although there is a substantial expansion of bone marrow MKs because of arrested MK development [25]. A dimorphic population of normal and dysmorphic MKs is present as a result of only one of the two FLI1 alleles being expressed in a single MK precursor in early development $[27,28]$.

\section{GATA-I}

GATA-1 is a member of the GATA TF family that binds to the GATA sequence on DNA. GATA-1 is an important regulator of both MK and erythroid development, and the encoding gene is located on the short arm of the $\mathrm{X}$ chromosome (Xp11.23) [30]. Two mutations in GATA-1 (V205M and D218G) have been connected to an $\mathrm{X}$-linked syndrome consisting of macrothrombocytopenia and dyserythropoiesis with or without anemia (MIM 300367) [31,32]. Such mutations have resulted in impaired GATA-1 interaction with the essential co-factor friend of GATA-1 (FOG1) [31,32]. Multiple platelet defects have been described in this syndrome, including selectively impaired responses to ristocetin and collagen owing to glycoprotein Ib and glycoprotein VI abnormalities, respectively. There is also reduced expression of platelet $\mathrm{G} \alpha \mathrm{S}$ mRNA and protein suggestive of incomplete maturation of MKs [32,33]. A sex-linked form of the gray platelet syndrome (GPS), a congenital platelet disorder characterized by macrothrombocytopenia and deficiency of $\alpha$-granules, in association with GATA-1 R216N mutation has also been described [34]. This entity had been referred to as X-linked thrombocytopenia with $\beta$ thalassemia. The $\mathrm{R} 216 \mathrm{~N}$ mutation is unique in that it results in decreased affinity between GATA- 1 and its palindromic site rather than disrupting interaction with its co-factor FOG1 [35]. Another identified GATA-1 mutation involves a splice site $(332 \mathrm{G}-\mathrm{C}, \mathrm{V} 74 \mathrm{~L})$ that produces a truncated variant of GATA- 1 and has been associated with the X-linked syndrome of anemia with or without neutropenia or platelet abnormalities or both (MIM 300835) [36].

\section{GFIIB}

GFI1B is a TF, which functions as a transcriptional repressor, that has been shown to be essential for MK and erythroid development. The encoding gene is located on the long arm of chromosome 9 (9q34.13) [37,38]. Two recent studies $[37,38]$ have implicated mutations in the zinc finger 5 DNA-binding domain region of GFI1B in autosomal dominant platelet disorders characterized by dysmegakaryopoiesis, macrothrombocytopenia, $\alpha$-granule deficiency, and variable bleeding tendency through distinct genetic mechanisms that produce a dominant-negative effect. The first study [37] identified a single nucleotide insertion in exon 7 (c880-881insC) that predicts a frameshift mutation in the fifth zinc finger DNA binding domain of GFI1B in a family with a bleeding disorder originally described in 1976 [37,39]. The family members were also found to have evidence of red cell anisopoikilocytosis, impaired platelet aggregation responses, and decreased platelet P-selectin, fibrinogen, glycoprotein $\mathrm{Ib} \alpha$, and glycoprotein IIIa [37]. The second study [38] uncovered a truncating mutation (c.859C>T), also within the fifth zinc finger DNA binding domain of GFI1B, in a family originally reported in 1968 and subsequently diagnosed with GPS $[38,40]$. The family members also had reduced platelet factor 4 and $\beta$ thromboglobulin as well as evidence of bone marrow myelofibrosis and emperipolesis (intact cell within cytoplasm of another cell) [38]. Identification of autosomal dominant genetic mechanisms in GPS is particularly noteworthy as previously described pedigrees in GPS have primarily been autosomal recessive, and three groups have reported biallelic mutations in the NBEAL2 gene, which encodes a BEACH protein involved in vesicular trafficking [41-43]. Interestingly, it was recently demonstrated in a murine knockout model that NBEAL2 deficiency results in loss of $\alpha$-granules from platelets after initial formation and proinflammatory MKs, which may drive GPS features including myelofibrosis, splenomegaly, and emperipolesis, with $\alpha$-granule loss also leading to protection from cancer metastasis [44]. Alpha-granule deficiency due to mutations in the gene encoding the VPS33B protein (a member of the Sec1/Munc18 protein family) and the VPS16B gene in the arthrogryposis multiplex congenita, renal dysfunction, and cholestasis (ARC) 
syndrome has also been described [45-47]. These studies highlight the heterogeneous mechanisms that can lead to $\alpha$-granule deficiency and GPS, including TF mutations involving RUNX1 [10,16], GATA-1 [34], and GFI1B [37].

From a different perspective, it is clear that these TF mutations are generally associated with a combination of thrombocytopenia and defects in platelet function, although in some instances there are associated abnormalities in red cells as well, as is the case for mutations in GATA-1 [30] and GFI1B [37].

\section{Conclusions}

In summary, evidence is now available that in some patients with impaired platelet aggregation and secretion responses on an inherited basis the primary genetic defect may be in a TF. TF mutations may be more common in such patients than generally considered. Most, but not all, of these patients have a variable degree of thrombocytopenia. The abnormalities in platelet number and function arise because of alterations in multiple pathways regulated by the TF. Some of the TF mutations have prognostic and treatment implications beyond the platelet defect, such as the association of myeloid malignancies with mutations in RUNX1 and donor selection for hematopoietic stem cell transplant $[6,7,21]$.

\section{Abbreviations}

AML, acute myeloid leukemia; FLI1, friend leukemia integration 1; FOG1, friend of GATA-binding factor 1; FPD, familial platelet disorder; GATA-1, GATA-binding factor 1; GFI1B, growth factor-independent 1B; GPS, gray platelet syndrome; iPSC, induced pluripotent stem cell; MDS, myelodysplastic syndrome; MIM, Mendelian Inheritance in Man; MK, megakaryocyte; RUNX1, Runtrelated transcription factor 1 ; SPD, storage pool deficiency; $\mathrm{TF}$, transcription factor.

\section{Disclosures}

The authors declare that they have no disclosures.

\section{References}

I. Rao AK: Inherited platelet function disorders: overview and disorders of granules, secretion, and signal transduction. Hematology/oncology clinics of North America 2013, 27:585-6II.

2. Stockley J, Morgan NV, Bem D, Lowe GC, Lordkipanidzé M, Dawood B, Simpson MA, Macfarlane K, Horner K, Leo VC, Talks K, Motwani J, Wilde JT, Collins PW, Makris M, Watson SP, Daly ME: Enrichment of FLII and RUNXI mutations in families with excessive bleeding and platelet dense granule secretion defects. Blood 2013, I 22:4090-3.

\section{FlOOOPrime}

3. Tijssen MR, Cvejic A, Joshi A, Hannah RL, Ferreira R, Forrai A, Bellissimo DC, Oram SH, Smethurst PA, Wilson NK, Wang $X$, Ottersbach K, Stemple DL, Green AR, Ouwehand WH, Göttgens B: Genome-wide analysis of simultaneous GATAI/2, RUNXI,
FLII, and SCL binding in megakaryocytes identifies hematopoietic regulators. Developmental cell 2011, 20:597-609.

\section{FIOOOPrime}

4. Mikhail FM, Sinha KK, Saunthararajah Y, Nucifora G: Normal and transforming functions of RUNXI: a perspective. Journal of cellular physiology 2006, 207:582-93.

5. Wang $Q$, Stacy $T$, Binder M, Marin-Padilla M, Sharpe AH, Speck NA: Disruption of the Cbfa2 gene causes necrosis and hemorrhaging in the central nervous system and blocks definitive hematopoiesis. Proceedings of the National Academy of Sciences of the United States of America 1996, 93:3444-9.

6. Song WJ, Sullivan MG, Legare RD, Hutchings $S$, Tan X, Kufrin D, Ratajczak J, Resende IC, Haworth C, Hock R, Loh M, Felix C, Roy DC, Busque L, Kurnit D, Willman C, Gewirtz AM, Speck NA, Bushweller JH, Li FP, Gardiner K, Poncz M, Maris JM, Gilliland DG: Haploinsufficiency of CBFA2 causes familial thrombocytopenia with propensity to develop acute myelogenous leukaemia. Nature genetics 1999, 23:166-75.

7. Liew E, Owen C: Familial myelodysplastic syndromes: a review of the literature. Haematologica 20II, 96:1536-42.

8. Connelly JP, Kwon EM, Gao Y, Trivedi NS, Elkahloun AG, Horwitz MS, Cheng L, Liu PP: Targeted correction of RUNXI mutation in FPD patient-specific induced pluripotent stem cells rescues megakaryopoietic defects. Blood 2014, 124: 1926-30.

\section{FlOOOPrime \\ RECOMMENDED}

9. Glembotsky AC, Bluteau D, Espasandin YR, Goette NP, Marta RF, Marin Oyarzun, CP, Korin L, Lev PR, Laguens RP, Molinas FC, Raslova H, Heller PG: Mechanisms underlying platelet function defect in a pedigree with familial platelet disorder with a predisposition to acute myelogenous leukemia: potential role for candidate RUNXI targets. Journal of thrombosis and haemostasis: JTH 20I4, 12:76I-72.

10. Michaud J, Wu F, Osato M, Cottles GM, Yanagida M, Asou N, Shigesada K, Ito $Y$, Benson KF, Raskind WH, Rossier C, Antonarakis SE, Israels S, McNicol A, Weiss H, Horwitz M, Scott HS: In vitro analyses of known and novel RUNXI/ AMLI mutations in dominant familial platelet disorder with predisposition to acute myelogenous leukemia: implications for mechanisms of pathogenesis. Blood 2002, 99:1364-72.

II. Antony-Debré I, Manchev VT, Balayn N, Bluteau D, Tomowiak C, Legrand C, Langlois T, Bawa O, Tosca L, Tachdjian G, Leheup B, Debili N, Plo I, Mills JA, French DL, Weiss MJ, Solary E, Favier R, Vainchenker W, Raslova H: Level of RUNXI activity is critical for leukemic predisposition but not for thrombocytopenia. Blood 20I5, I25:930-40.

\section{FlOOOPrime}

\section{RECOMMENDED}

12. Sun L, Mao G, Rao AK: Association of CBFA2 mutation with decreased platelet PKC-theta and impaired receptormediated activation of GPIlb-IIla and pleckstrin phosphorylation: proteins regulated by CBFA2 play a role in GPIIb-IIla activation. Blood 2004, 103:948-54.

13. Kaur G, Jalagadugula G, Mao G, Rao AK: RUNXI/core binding factor A2 regulates platelet I 2-lipoxygenase gene (ALOX I2): studies in human RUNXI haplodeficiency. Blood 2010, I 1 5:3128-35.

14. Weiss HJ, Chervenick PA, Zalusky R, Factor A: A familialdefect in platelet function associated with imapired release of adenosine diphosphate. The New England journal of medicine 1969, 28 I: $1264-70$

15. Weiss HJ, Witte LD, Kaplan KL, Lages BA, Chernoff A, Nossel HL, Goodman DS, Baumgartner HR: Heterogeneity in storage pool deficiency: studies on granule-bound substances in 18 patients including variants deficient in alpha-granules, platelet factor 4, beta-thromboglobulin, and platelet-derived growth factor. Blood 1979, 54:1296-319. 
16. Aneja K, Jalagadugula G, Mao G, Singh A, Rao AK: Mechanism of platelet factor 4 (PF4) deficiency with RUNXI haplodeficiency: RUNXI is a transcriptional regulator of PF4. Journal of thrombosis and haemostasis: JTH 20II, 9:383-9I.

17. Sun L, Gorospe JR, Hoffman EP, Rao AK: Decreased platelet expression of myosin regulatory light chain polypeptide (MYL9) and other genes with platelet dysfunction and CBFA2/RUNXI mutation: insights from platelet expression profiling. Journal of thrombosis and haemostasis: JTH 2007, 5: | 46-54.

18. Jalagadugula G, Mao G, Kaur G, Goldfinger LE, Dhanasekaran DN, Rao AK: Regulation of platelet myosin light chain (MYL9) by RUNXI: implications for thrombocytopenia and platelet dysfunction in RUNXI haplodeficiency. Blood 2010, I I 6:6037-45.

19. Jalagadugula G, Mao G, Kaur G, Dhanasekaran DN, Rao AK: Platelet protein kinase C-theta deficiency with human RUNXI mutation: PRKCQ is a transcriptional target of RUNXI. Arteriosclerosis, thrombosis, and vascular biology 201 I, 31:921-7.

20. Heller PG, Glembotsky AC, Gandhi MJ, Cummings CL, Pirola Cl, Marta RF, Kornblihtt LI, Drachman JG, Molinas FC: Low Mpl receptor expression in a pedigree with familial platelet disorder with predisposition to acute myelogenous leukemia and a novel AMLI mutation. Blood 2005, 105:4664-70.

\section{FlOOOPrime}

21. Owen CJ, Toze CL, Koochin A, Forrest DL, Smith CA, Stevens JM, Jackson SC, Poon M, Sinclair GD, Leber B, Johnson, Peter RE, Macheta A, Yin, John AL, Barnett MJ, Lister TA, Fitzgibbon J: Five new pedigrees with inherited RUNXI mutations causing familial platelet disorder with propensity to myeloid malignancy. Blood 2008, I I 2:4639-45.

\section{FlOOOPrime}

22. Bastian LS, Kwiatkowski BA, Breininger J, Danner S, Roth G: Regulation of the megakaryocytic glycoprotein IX promoter by the oncogenic Ets transcription factor Fli-I. Blood 1999, 93:2637-44

23. Hashimoto $Y$, Ware I: Identification of essential GATA and Ets binding motifs within the promoter of the platelet glycoprotein Ib alpha gene. The Journal of biological chemistry 1995, 270:24532-9.

24. Deveaux S, Filipe A, Lemarchandel V, Ghysdael J, Roméo PH, Mignotte V: Analysis of the thrombopoietin receptor (MPL) promoter implicates GATA and Ets proteins in the coregulation of megakaryocyte-specific genes. Blood 1996, 87:4678-85.

25. Breton-Gorius J, Favier R, Guichard J, Cherif D, Berger R, Debili N, Vainchenker W, Douay L: A new congenital dysmegakaryopoietic thrombocytopenia (Paris-Trousseau) associated with giant platelet alpha-granules and chromosome II deletion at I Iq23. Blood I995, 85:1805-I4.

26. Favier R, Jondeau K, Boutard $P$, Grossfeld $P$, Reinert $P$, Jones $C$, Bertoni $F$, Cramer EM: Paris-Trousseau syndrome. Clinical, hematological, molecular data of ten new cases. Thrombosis and haemostasis 2003, 90:893-7.

27. Raslova H, Komura E, Le Couédic, Jean Pierre, Larbret F, Debili N, Feunteun J, Danos O, Albagli O, Vainchenker W, Favier R: FLII monoallelic expression combined with its hemizygous loss underlies Paris-Trousseau/Jacobsen thrombopenia. The Journal of clinical investigation 2004, I | 4:77-84.

28. Shivdasani RA: Lonely in Paris: when one gene copy isn't enough. The Journal of clinical investigation 2004, I 14:17-9.

29. Jacobsen P, Hauge M, Henningsen K, Hobolth N, Mikkelsen M, Philip J: An $(I I ; 2 I)$ translocation in four generations with chromosome II abnormalities in the offspring. A clinical, cytogenetical, and gene marker study. Human heredity 1973, 23:568-85.

30. Kumar R, Kahr, Walter HA: Congenital thrombocytopenia: clinical manifestations, laboratory abnormalities, and molecular defects of a heterogeneous group of conditions. Hematology/oncology clinics of North America 2013, 27:465-94.
3I. Nichols KE, Crispino JD, Poncz M, White JG, Orkin SH, Maris JM, Weiss MJ: Familial dyserythropoietic anaemia and thrombocytopenia due to an inherited mutation in GATAI. Nature genetics 2000, 24:266-70.

32. Freson K, Devriendt K, Matthijs G, van Hoof A, Vos R de, Thys C, Minner K, Hoylaerts MF, Vermylen J, van Geet C: Platelet characteristics in patients with $\mathrm{X}$-linked macrothrombocytopenia because of a novel GATAI mutation. Blood 200I, 98:85-92.

33. Hughan SC, Senis Y, Best D, Thomas A, Frampton J, Vyas P, Watson SP: Selective impairment of platelet activation to collagen in the absence of GATAI. Blood 2005, 105:4369-76.

34. Tubman VN, Levine JE, Campagna DR, Monahan-Earley R, Dvorak AM, Neufeld EJ, Fleming MD: X-linked gray platelet syndrome due to a GATAI Arg2 I6GIn mutation. Blood 2007, 109:3297-9.

35. Yu C, Niakan KK, Matsushita M, Stamatoyannopoulos G, Orkin SH, Raskind WH: X-linked thrombocytopenia with thalassemia from a mutation in the amino finger of GATA-I affecting DNA binding rather than FOG-I interaction. Blood 2002, 100:2040-5.

36. Hollanda LM, Lima, Carmen SP, Cunha AF, Albuquerque DM, Vassallo J, Ozelo MC, Joazeiro PP, Saad, Sara TO, Costa FF: An inherited mutation leading to production of only the short isoform of GATA-I is associated with impaired erythropoiesis. Nature genetics 2006, 38:807-I2.

37. Stevenson WS, Morel-Kopp M, Chen Q, Liang HP, Bromhead CJ, Wright S, Turakulov R, Ng AP, Roberts AW, Bahlo M, Ward CM: GFIIB mutation causes a bleeding disorder with abnormal platelet function. Journal of thrombosis and haemostasis: JTH 2013, I I:2039-47.

\section{FlOOOPrime \\ RECOMMENDED}

38. Monteferrario D, Bolar NA, Marneth AE, Hebeda KM, Bergevoet SM, Veenstra H, Laros-van Gorkom, Britta AP, MacKenzie MA, Khandanpour C, Botezatu L, Fransen E, van Camp G, Duijnhouwer AL, Salemink S, Willemsen B, Huls G, Preijers F, van Heerde W, Jansen JH, Kempers, Marlies JE, Loeys BL, van Laer L, Van der Reijden, Bert A: A dominant-negative GFIIB mutation in the gray platelet syndrome. The New England journal of medicine 2014, 370:245-53.

\section{FlOOOPrime} RECOMMENDED

39. Ardlie NG, Coupland WW, Schoefl GI: Hereditary thrombocytopathy: a familial bleeding disorder due to impaired platelet coagulant activity. Australian and New Zealand journal of medicine 1976, 6:37-45.

40. Kurstjens R, Bolt C, Vossen M, Haanen C: Familial thrombopathic thrombocytopenia. British journal of haematology 1968, 15:305-17.

4I. Gunay-Aygun M, Falik-Zaccai TC, Vilboux T, Zivony-Elboum Y, Gumruk F, Cetin M, Khayat M, Boerkoel CF, Kfir N, Huang Y, Maynard D, Dorward H, Berger K, Kleta R, Anikster Y, Arat M, Freiberg AS, Kehrel BE, Jurk K, Cruz P, Mullikin JC, White JG, Huizing M, Gahl WA: NBEAL2 is mutated in gray platelet syndrome and is required for biogenesis of platelet $\alpha$-granules. Nature genetics 20II, 43:732-4

\section{FlOOOPrime \\ RECOMMENDED}

42. Albers CA, Cvejic A, Favier R, Bouwmans EE, Alessi M, Bertone P, Jordan G, Kettleborough, Ross NW, Kiddle G, Kostadima M, Read RJ, Sipos B, Sivapalaratnam S, Smethurst PA, Stephens J, Voss K, Nurden A, Rendon A, Nurden P, Ouwehand WH: Exome sequencing identifies NBEAL2 as the causative gene for gray platelet syndrome. Nature genetics 20II, 43:735-7.

\section{FlOOOPrime}

RECOMMENDED

43. Kahr, Walter HA, Hinckley J, Li L, Schwertz H, Christensen H, Rowley JW, Pluthero FG, Urban D, Fabbro S, Nixon B, Gadzinski R, Storck M, Wang K, Ryu G, Jobe SM, Schutte BC, Moseley J, 
Loughran NB, Parkinson J, Weyrich AS, Di Paola J: Mutations in NBEAL2, encoding a BEACH protein, cause gray platelet syndrome. Nature genetics 20I I, 43:738-40.

\section{FlOOOPrime}

\section{RECOMMENDED}

44. Guerrero JA, Bennett $C$, van der Weyden, Louise, McKinney $H$, Chin M, Nurden P, Mclntyre Z, Cambridge EL, Estabel J, WardleJones $H$, Speak $A O$, Erber $W N$, Rendon $A$, Ouwehand $W H$, Ghevaert C: Gray platelet syndrome: proinflammatory megakaryocytes and $\alpha$-granule loss cause myelofibrosis and confer metastasis resistance in mice. Blood 2014, 124:3624-35.

\section{FIOOOPrime \\ RECOMMENDED}

45. Gissen P, Johnson CA, Morgan NV, Stapelbroek JM, Forshew T, Cooper WN, McKiernan PJ, Klomp, Leo WJ, Morris, Andrew AM, Wraith JE, McClean P, Lynch SA, Thompson RJ, Lo B, Quarrell OW, Di Rocco M, Trembath RC, Mandel H, Wali S, Karet FE, Knisely AS, Houwen, Roderick HJ, Kelly DA, Maher ER: Mutations in VPS33B, encoding a regulator of SNARE-dependent membrane fusion, cause arthrogryposis-renal dysfunction-cholestasis (ARC) syndrome. Nature genetics 2004, 36:400-4.

\section{FlOOOPrime}

RECOMMENDED

46. Lo B, Li L, Gissen P, Christensen H, McKiernan PJ, Ye C, Abdelhaleem M, Hayes JA, Williams MD, Chitayat D, Kahr, Walter HA: Requirement of VPS33B, a member of the Secl/Muncl 8 protein family, in megakaryocyte and platelet alpha-granule biogenesis. Blood 2005, 106:4159-66.

\section{FlOOOPrime}

RECOMMENDED

47. Urban D, Li L, Christensen H, Pluthero FG, Chen SZ, Puhacz M, Garg PM, Lanka KK, Cummings JJ, Kramer H, Wasmuth JD, Parkinson J, Kahr, Walter HA: The VPS33B-binding protein VPSI6B is required in megakaryocyte and platelet $\alpha$-granule biogenesis. Blood 2012, 120:5032-40.

\section{FlOOOPrime}

